\title{
Eliminasi Cairan dengan Target Balans Cairan Negatif pada Pasien Bedah Sesar dengan Gagal Jantung, Penyakit Jantung Kanan, Hipertensi Pulmonal dan Pasca Repair Katup Mitral
}

\section{Fluid Removal with Negative Fluid Balance in Caessarean Section Patient with Congestive Heart Failure, Right Heart Disease, Pulmonary Hypertension and Post Mitral Valve Repair}

\author{
Sabar Hamonangan Victorianus Napitu ${ }^{\bigotimes *}$, Amir S. Madjid ${ }^{* *}$, Indro Muljono** \\ *RSUD dr. Djasamen Saragih Pematang Siantar, Sumatera Utara, Indonesia \\ ** Departemen Anestesiologi dan Terapi Intensif, Fakultas Kedokteran, Universitas Indonesia, \\ Jakarta \\ ${ }^{\square}$ Korespondensi: sabarhvnapitu@gmail.com
}

\begin{abstract}
Background: Pregnancy with heart problem is a challenge in handling critical care patients. Right heart disease (RHD) that causes mitral regurgitation (MR) followed by congestive heart failure (CHF) that happens to pregnant women causes fluid overload with all its consequences. Standard guideline regarding fluid removal in terms of the volume of fluid being removed, duration, timing to start and to end is not yet available.

Case: Fluid removal is done by administering diuretic from day I to day IV at 2-5 $\mathrm{mg} /$ hour dose by titration. The fluid removal guide used is the patient's general clinical condition, coupled with parameters such as blood pressure, heart rate, urine output, cumulative fluid balance, level of need for hemodynamic support medications, hemoglobin/ hematocrit ratio, ureum, creatinine, lactate, and base excess (dynamic macro and micro parameters).

Discussion: Combination of fluid removal with negative fluid balance, adequate oxygenation during ventilation and after extubation and appropriate pharmacologic therapy provides good synergistic effect on patient recovery.

Conclusion: Strict monitoring is needed to achieve negative fluid balance without adverse effects.
\end{abstract}

Keywords: diuretic; fluid overload; fluid removal; negative fluid balance; pregnancy

\begin{abstract}
ABSTRAK
Latar Belakang: Kehamilan dengan permasalahan jantung merupakan sebuah tantangan dalam pengelolaan pasien-pasien kritis. Right heart disease (RHD) yang menyebabkan mitral regurgitation (MR) dan selanjutnya diikuti oleh congestive heart failure (CHF) yang terjadi pada ibu hamil menyebabkan fluid overload dengan segala konsekuensinya. Fluid removal dengan target balans cairan negatif merupakan strategi pengelolaan pada kondisi tersebut.
\end{abstract}


Kasus: Untuk kasus ini, fluid removal dilakukan dengan pemberian diuretik (Furosemide) sejak hari I sampai dengan IV dengan dosis $2-5 \mathrm{mg} / \mathrm{jam}$ secara titrasi. Panduan fluid removal yang digunakan adalah kondisi klinis pasien secara umum, ditambah dengan parameter seperti: tekanan darah, heart rate, urine output, balans cairan kumulatif, tingkat kebutuhan akan obat-obat penopang hemodinamik, rasio hemoglobin/hematokrit, ureum, kreatinin, laktat, dan BE (parameter makro dan mikro dinamik).

Pembahasan: Panduan baku tentang fluid removal baik dalam hal volume cairan yang ditarik, durasi, dan timing untuk memulai dan mengakhiri belum ada.

Kesimpulan: Diperlukan monitoring ketat untuk mencapai balans cairan negatif tanpa menimbulkan efek samping.

Kata Kunci: balans cairan negatif; diuretik; fluid overload; fluid removal; kehamilan

\section{PENDAHULUAN}

Malbrain et al., menyatakan bahwa balans cairan kumulatif positif berhubungan dengan hipertensi intra abdomen (IAH) dan outcome yang buruk. ${ }^{1}$ Pencegahan terjadinya balans cairan kumulatif positif berhubungan dengan perbaikan outcome. Konsep deresusitasi didasarkan kepada adanya tindakan resusitasi cairan untuk mempertahankan hemodinamik dan perfusi jaringan sebelumnya. Bila tindakan dilakukan tanpa adanya resusitasi cairan sebelumnya lebih tepat disebut fluid removal, seperti halnya pada pasien dalam laporan kasus ini.

Targetnya adalah mencapai balans cairan negatif melalui mobilisasi cairan yang terakumulasi. Dalam kondisi sakit kritis, sebagian pasien membutuhkan fluid removal yang dilakukan dengan lebih aktif dan agresif dengan menggunakan diuretik atau renal replacement therapy (RRT) dengan ultrafiltrasi.

Banyak studi telah menunjukkan bahwa balans cairan positif secara bebas berkorelasi dengan gangguan fungsi organ dan peningkatan risiko mortalitas. ${ }^{2}$ Hal ini telah ditunjukkan pada studi yang dilakukan oleh
Murphy et al. ${ }^{3}$ Balans cairan negatif yang dicapai dengan deresusitasi pada hari ke-3 perawatan di intensive care unit (ICU) berhubungan dengan perbaikan outcome pasien. Meminimalkan balans cairan dalam 3 hari pertama dengan membatasi intake cairan maintenance dan pengenceran obat sambil melakukan tindakan deresusitasi menunjukkan strategi terapi yang berpotensi menguntungkan yang masih membutuhkan investigasi dalam suatu penelitian acak. ${ }^{4}$

Tercapainya balans cairan negatif berhubungan dengan perbaikan fungsi organ dan survival rate. ${ }^{5,6}$ Data terbaru menunjukkan bahwa banyak pasien tidak dapat masuk ke fase flow secara spontan, sehingga untuk mencegah balans cairan kumulatif positif dengan risiko edema dan disfungsi organ, mereka membutuhkan terapi intervensi. ${ }^{7}$

\section{KASUS}

Pasien perempuan, 38 tahun, $\mathrm{G}_{2} \mathrm{P}_{1} \mathrm{~A}_{0}$ hamil aterm dengan riwayat penyakit jantung kanan, regurgitasi katup mitral, post mitral valve repair, gagal jantung kongestif, dan hipertensi pulmonal menjalani operasi bedah sesar, anestesi umum dengan intubasi endotrakeal. 


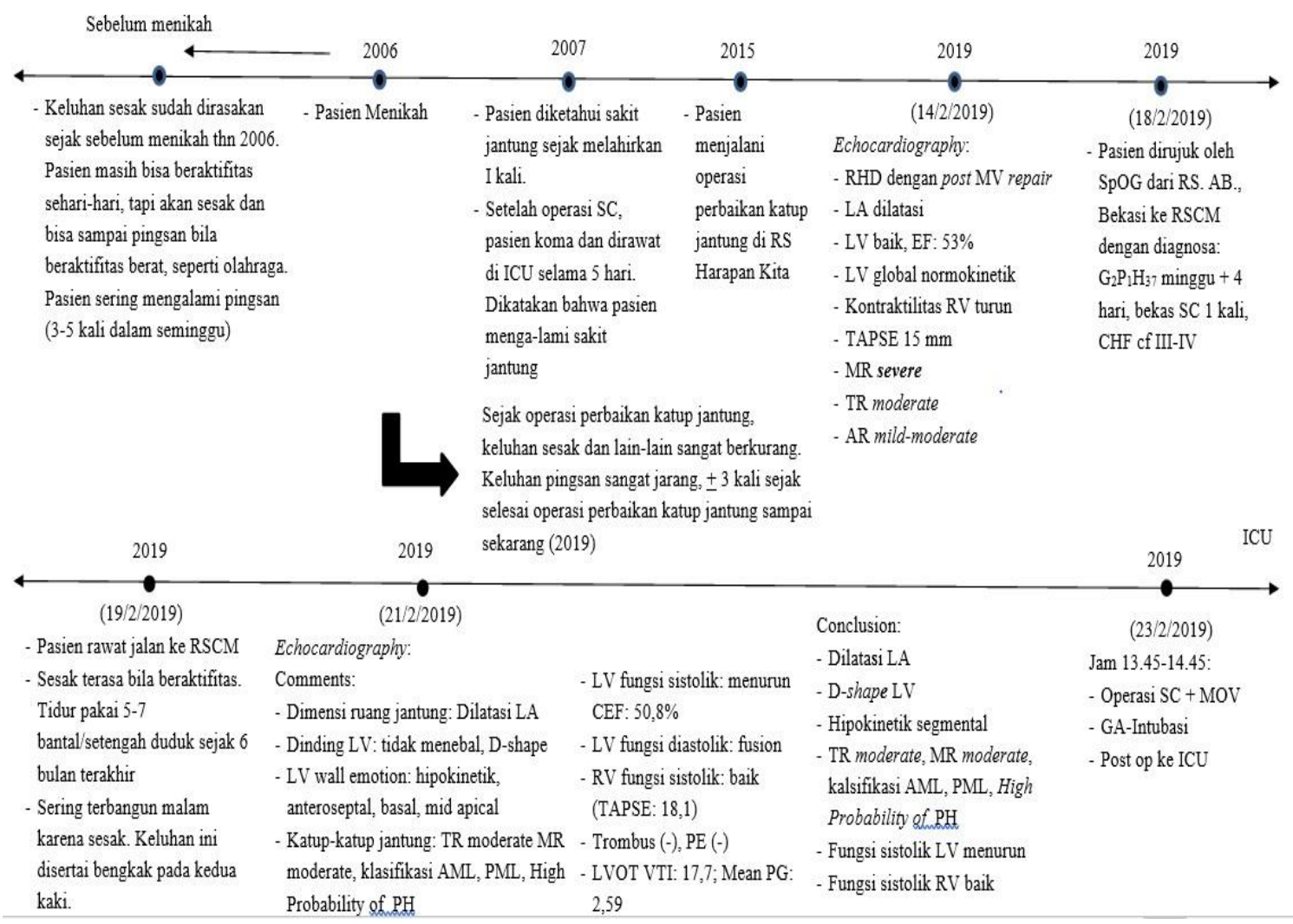

Gambar 1. Perjalanan penyakit pasien

Tabel 1. Follo up pasien di ICU

\begin{tabular}{|c|c|c|c|c|c|c|}
\hline Parameter & $\begin{array}{c}\text { Hari I (23- } \\
\text { 24/2/2019); } \\
\text { Jam : } \\
16.00-06.00\end{array}$ & $\begin{array}{c}\text { Hari II (24- } \\
25 / 2 / 2019) \text {; } \\
\text { Jam : } \\
06.00-06.00\end{array}$ & $\begin{array}{c}\text { Hari III } \\
(25- \\
26 / 2 / 2019) ; \\
\text { Jam : } \\
06.00-06.00\end{array}$ & $\begin{array}{c}\text { Hari IV } \\
(26- \\
27 / 2 / 2019) ; \\
\text { Jam : } \\
06.00-06.00\end{array}$ & $\begin{array}{c}\text { Hari V (27- } \\
\text { 28/2/2019); } \\
\text { Jam 06.00- } \\
06.00\end{array}$ & $\begin{array}{c}\text { Hari VI } \\
(28 / 2 / 2019) ; \\
\text { Jam : 06.00- } \\
09.00\end{array}$ \\
\hline $\begin{array}{l}\text { Tekanan } \\
\text { darah } \\
(\mathrm{mmHg})\end{array}$ & $\begin{array}{c}95-130 / 60- \\
80\end{array}$ & $\begin{array}{c}110- \\
130 / 70-80\end{array}$ & $\begin{array}{c}105- \\
133 / 60-75\end{array}$ & $\begin{array}{c}110- \\
130 / 60-80\end{array}$ & $\begin{array}{c}100- \\
130 / 50-75\end{array}$ & $\begin{array}{c}95-110 / 57- \\
63\end{array}$ \\
\hline $\begin{array}{l}\text { Heart rate } \\
(\mathrm{x} / \mathrm{mnt})\end{array}$ & $120-145$ & $100-150$ & $95-115$ & $90-102$ & $82-100$ & $82-90$ \\
\hline $\begin{array}{l}\text { Respiration } \\
\text { rate }(\mathrm{x} / \mathrm{mnt})\end{array}$ & $15-16$ & $16-20$ & $15-21$ & $15-22$ & $16-24$ & $16-20$ \\
\hline $\operatorname{Suhu}\left({ }^{\circ} \mathrm{C}\right)$ & $36.4-36,9$ & $36,5-38,3$ & $36,1-38,1$ & $36,0-38,5$ & $36,0-36,8$ & $36,0-36,8$ \\
\hline $\begin{array}{l}\text { CVP } \\
(\mathrm{mmHg})\end{array}$ & $11-12$ & $15-16$ & $11-15$ & 6-8 & $8-12$ & $6-7$ \\
\hline $\begin{array}{l}\text { Urine } \\
\text { output } \\
\text { (ml/kg/jam) }\end{array}$ & 0,39 & 1,17 & 1,4 & 0,88 & 1,5 & - \\
\hline $\begin{array}{l}\text { Balans } \\
\text { cairan } \\
\text { kumulatif } \\
(\mathrm{ml})\end{array}$ & $\begin{array}{c}+55,4(14 \\
\text { jam })\end{array}$ & $-801,4$ & $-1827,6$ & $-1891,6$ & $-3192,4$ & - \\
\hline
\end{tabular}


Parameter Makrodinamik

Setelah operasi bedah sesar, pasien dirawat di ICU dengan terintubasi, on ventilator, PSIMV 14, PC 12, PEEP 5, $\mathrm{FiO}_{2} 40 \%, \mathrm{SpO}_{2} 99-100 \%$, tekanan darah
95-130/ 60-80 mmHg, frekuensi nadi 120-145x/menit, edema ekstremitas inferior $+/+$, topangan: Dobutamine 3-5 $\mathrm{mcg} / \mathrm{kg} / \mathrm{menit}$, iv, titrasi dan Milrinon $0,1-0,2 \mathrm{mcg} / \mathrm{kg} / \mathrm{menit}$, iv, titrasi.

Parameter Mikrodinamik

\begin{tabular}{lllllll}
\hline Parameter & Hari I & Hari II & Hari III & Hari IV & Hari V & Hari VI \\
\hline Laktat & 1,5 & 0,7 & 1,1 & 0,7 & 1,1 & - \\
AGD/BE & Jam 16,53 & Jam 04,47 & Jam 04,18 & Jam 05,13 & Jam 14,25 & \\
& $\mathrm{PH}=7,291$ & $\mathrm{PH}=7,448$ & $\mathrm{PH}=7,457$ & $\mathrm{PH}=7,438$ & $\mathrm{PH}=7,452$ & $\mathrm{Ph}=7,504$ \\
& $\mathrm{pCO} 2=$ & $\mathrm{pCO} 2=$ & $\mathrm{pCO} 2=$ & $\mathrm{pCO}=43,6$ & $\mathrm{pCO} 2=33,5$ & $\mathrm{pCO} 2=39,9$ \\
& 42,9 & 35,8 & 35,8 & $\mathrm{pO}=139,3$ & $\mathrm{pO} 2=185,0$ & $\mathrm{pO} 2=175,3$ \\
& $\mathrm{pO} 2=$ & $\mathrm{pO} 2=$ & $\mathrm{pO} 2=$ & $\mathrm{HCO}=$ & $\mathrm{HCO}=$ & $\mathrm{HCO}=$ \\
& 103,9 & 187,1 & 164,9 & 29,8 & 23,7 & 31,6 \\
& $\mathrm{HCO}=21$ & $\mathrm{HCO}=$ & $\mathrm{HCO}=$ & $\mathrm{BE}=5,9$ & $\mathrm{BE}=0,6$ & $\mathrm{BE}=8,4$ \\
& $\mathrm{BE}=-4,6$ & 24,9 & 25,5 & & & \\
& & $\mathrm{BE}=1,6$ & $\mathrm{BE}=2,2$ & & & \\
\hline
\end{tabular}

\section{Parameter lain}

\begin{tabular}{|c|c|c|c|c|c|c|}
\hline Parameter & $\begin{array}{r}\text { Hari I } \\
(23-24 / 2 / 2019)\end{array}$ & $\begin{array}{c}\text { Hari II } \\
(24- \\
25 / 2 / 2019)\end{array}$ & $\begin{array}{c}\text { Hari III } \\
(25- \\
26 / 2 / 2019)\end{array}$ & $\begin{array}{c}\text { Hari IV } \\
(26- \\
27 / 2 / 2019)\end{array}$ & $\begin{array}{c}\text { Hari V } \\
(27- \\
28 / 2 / 2019)\end{array}$ & $\begin{array}{c}\text { Hari VI } \\
(28 / 2 / 2019 \\
)\end{array}$ \\
\hline Ureum & 16,2 & 18,6 & 19,0 & 19,5 & - & - \\
\hline Kreatinin & 0,48 & 0,54 & 0,59 & 0,55 & - & - \\
\hline SOOT & 20 & 24,4 & - & - & - & - \\
\hline SOPT & 21 & 21,4 & - & - & - & - \\
\hline Bil-Total & 1,2 & - & - & - & - & - \\
\hline Bil-Direk & 0,56 & - & - & - & - & - \\
\hline $\begin{array}{l}\text { Bil- } \\
\text { Indirek }\end{array}$ & 0,46 & - & - & - & - & - \\
\hline $\begin{array}{l}\text { Elektrolit } \\
\mathrm{Na} / \mathrm{K} / \mathrm{Cl}\end{array}$ & $134 / 3,9 / 110$ & $\begin{array}{c}135 / 3,2 / 10 \\
7\end{array}$ & $\begin{array}{c}138 / 3,7 / 10 \\
2\end{array}$ & $138 / 4,2 / 104$ & $\begin{array}{c}136 / 3,9 / 10 \\
9\end{array}$ & $\begin{array}{c}139 / 3,8 / 10 \\
4\end{array}$ \\
\hline $\begin{array}{l}\text { Foto } \\
\text { toraks }\end{array}$ & $\begin{array}{l}\text { Foto toraks: } \\
\text { - Kardiomegali dengan } \\
\text { awal bendungan paru } \\
\text { - ETT dengan tip tepat } \\
\text { di atas karina } \\
\text { - CVC dengan tip } \\
\text { proyeksi atrium kiri } \\
\text { - Tiadk tampak } \\
\text { pneumotoraks,pneumo } \\
\text {-mediatinum dan } \\
\text { emfisema sub kutis }\end{array}$ & - & - & $\begin{array}{l}\text { Dibandingkan } \\
\text { dengan foto } \\
\text { toraks } \\
\text { sebelumnya, } \\
\text { saat ini: } \\
\text { - Kardiomegal } \\
\text { i } \\
\text { - ETT dengan } \\
\text { tip } \pm 1 \text { cm di } \\
\text { atas karina } \\
\text { - CVC dengan } \\
\text { posisi } \\
\text { relative stqa }\end{array}$ & - & - \\
\hline $\begin{array}{l}\mathrm{PaO} 2 / \mathrm{FiO} \\
2\end{array}$ & 259,75 & 467,75 & 412,25 & 348,25 & 462,25 & 438,25 \\
\hline $\mathrm{Hb}$ & 10,3 & 8,5 & 9,3 & 9 & - & - \\
\hline
\end{tabular}




\begin{tabular}{|c|c|c|c|}
\hline Echocardiography & $\begin{array}{l}\text { Tanggal 14/2/2019 } \\
\text { (sebelum ICU) }\end{array}$ & $\begin{array}{l}\text { Tanggal 21/2/2019 (sebelum } \\
\text { ICU) }\end{array}$ & $\begin{array}{l}\text { Tanggal 26/2/2019 } \\
\text { (Hari IV di ICU) }\end{array}$ \\
\hline & $\begin{array}{l}\text {-RHD dengan post } \\
\text { MV repair } \\
\text {-LA dilatasi } \\
\text {-LV baik, EF } 53 \% \\
\text {-LV global } \\
\text { normokinetik } \\
\text {-Kontraktilitas RV } \\
\text { turun } \\
\text {-TAPSE: } 15 \mathrm{~mm} \\
\text {-MR severe,TR } \\
\text { moderate,AR mild- } \\
\text { moderate }\end{array}$ & $\begin{array}{l}\text { Comments: } \\
\text { - Dimensi ruang jantung: } \\
\text { dilatasi LA } \\
\text { - Didnding LV: tidak } \\
\text { menebal, D-shape } \\
\text { - LV wall motion: hipokinetik } \\
\text { anteroseptal, basal, mid, } \\
\text { apikal } \\
\text { - Katup-katup jantung: TR, } \\
\text { moderate, MR moderate, } \\
\text { kalsifikasi AML, PML, } \\
\text { High Probability of PH } \\
\text { - LV fungsi sistolik: menurun } \\
\text { (EF: 50.8\%) } \\
\text { - LV fungsi diastolic: fusion } \\
\text { - RV fungsi sistolik: baik, } \\
\text { TAPSE: 18,1 mm } \\
\text { - Trombus (-), PE (-) } \\
\text { - LVOT VTI:17,7, mean } \\
\text { PG:2,59 } \\
\text { - Conclusion: } \\
\text { - Dilatasi LA } \\
\text { - D-shape LV } \\
\text { - Hipokinetik segmental } \\
\text { - TR moderate, kalsifikasi } \\
\text { AML, PML, } \\
\text { - High Probability of PH } \\
\text { - Fungsi sistolik LV menurun } \\
\text { - Fungsi sistolik RV baik }\end{array}$ & $\begin{array}{l}\text { - } \text { Global } \\
\text { normokinetik } \\
\text { - LA dilatasi } \\
\text { - Fungsi sistolik } \\
\text { LV baik, EF: } \\
\text { 62\% } \\
\text { - Fungsi sistolik: } \\
\text { RV baik, } \\
\text { TAPSE: >18 mm } \\
\text { - Fungsi diastolik } \\
\text { LVbaik } \\
\text { - Katup mitral: } \\
\text { MR, mild, } \\
\text { vegetasi tidak } \\
\text { ada } \\
\text { - Tidak tampak } \\
\text { tanda-tanda PH }\end{array}$ \\
\hline
\end{tabular}

\section{PEMBAHASAN}

Selama masa perawatan di ICU, masalah utama yang ditemukan adalah masalah hemodinamik yang terkait dengan penyakit dasarnya, yaitu: RHD, MR, $\mathrm{CHF}$, dan $\mathrm{PH}$.

Dari grafik-grafik di atas (1, 2, 3, dan 4), tampak korelasi linier antara tindakan fluid removal dengan parameter tekanan darah, frekuensi nadi, urine output, dan balans cairan kumulatif. Balans cairan yang negatif disertai urine output yang cukup, dan perbaikan hemodinamik yang tampak dari frekuensi nadi yang semakin membaik (tidak takikardi lagi sejak hari IV).
Terapi yang diberikan pada pasien ini adalah digoksin, dobutamin dan milrinone. Digoksin dengan dosis 0,25 $\mathrm{mg} / 12$ jam iv drip dalam 20 menit sejak hari II sampai IV, dan dilanjutkan dengan dosis $0,25 \mathrm{mg} / 12$ jam per oral sampai hari VI. Digoksin mempunyai efek kronotropik negatif. Dengan pemberian digoksin tersebut, terjadi sinergi antara efek positif fluid removal terhadap fluid overload dan pemberian digoksin dalam mengatasi takikardi, sehingga pada hari IV pasien tidak mengalami takikardi lagi. Digoksin juga bersifat inotropik positif. Dobutamin dengan dosis titrasi sejak hari I-V. Dobutamin bersifat inotropik dan 
vasodilator perifer. Milrinone dengan dosis titrasi sejak hari I-V. Milrinone berefek vasodilator dan inotropik yang signifikan, baik pada pembuluh darah pulmoner maupun sistemik.

Kombinasi ketiga obat di atas akan mengatasi left ventricle (LV) dan right ventricle (RV) dysfunction dan peningkatan pulmonary vascular resistance (PVR) dan sistemik, sehingga meningkatkan stroke volume dan cardiac output dan mengatasi backward failure. Mekanisme ini bekerja sinergis dengan efek positif dari fluid removal (mengatasi edema) dan efek kronotropik dari digoksin dalam mengatasi takikardi, sehingga tercapai keseimbangan antara $\mathrm{DO}_{2}$ dan $\mathrm{VO}_{2}$ melalui peningkatan $\mathrm{DO}_{2}$ (melalui efek inotropik) dan penurunan $\mathrm{VO}_{2}$ (melalui penurunan denyut jantung atau frekuensi nadi).

Tindakan fluid removal sampai balans cairan kumulatif negatif menyebabkan perbaikan dari efek-efek patofisiologis akibat fluid overload terhadap sistem kardiovaskular melalui pengurangan preload dan volume intra vaskuler pada pasien yang pada dasarnya telah mengalami volume overload (karena kombinasi antara peningkatan volume plasma sebesar $30-40 \%$ sebagai konsekuensi fisiologis dari kehamilan dan MR kronis).

Dengan fluid removal, LV failure, edema paru, $\mathrm{PH}$, dan disfungsi ventrikel kanan (RV dysfunction) yang terjadi pada pasien ini mengalami perbaikan.
LV yang telah mengalami gangguan fungsi sistolik maupun diastolik akan mengalami pengurangan beban, sehingga dapat berfungsi dengan lebih efektif dan efisien. Efek backward failure dari LV failure teratasi. Hal ini tampak dari perbaikan parameter makrodinamik seperti: tekanan darah yang tetap optimal dan frekuensi nadi yang semakin membaik (tidak takikardia lagi sejak hari IV), urine output yang cukup, edema ekstremitas inferior berkurang sampai minimal pada hari IV. Demikian juga dengan parameter mikrodinamik seperti laktat yang tetap normal dan nilai BE yang membaik, yang menggambarkan perfusi ke organ dan jaringan yang tetap tercukupi, dan nilai ureum dan kreatinin serum yang tetap dalam level aman. Memang sampai saat ini belum ada panduan baku tentang bagaimana penatalaksanaan fluid removal, masih bersifat individual baik menyangkut volume, durasi, dan timing untuk memulai dan mengakhirinya. Untuk pasien ini, outcome klinis dan parameter di atas, yang semuanya berkorelasi positif dengan perbaikan menjadi panduan yang digunakan. Fluid removal mengatasi masalah utama yaitu fluid overload dengan segala akibatnya.

Dari grafik 5, tampak bahwa nilai central venous pressure (CVP) tidak stabil dan cenderung tetap tinggi. Hal ini sesuai dengan kondisi pasien yang mengalami gagal jantung yang disertai PH dan TR, sehingga parameter CVP tidak berkorelasi linier dengan perbaikan hemodinamik pasien. 


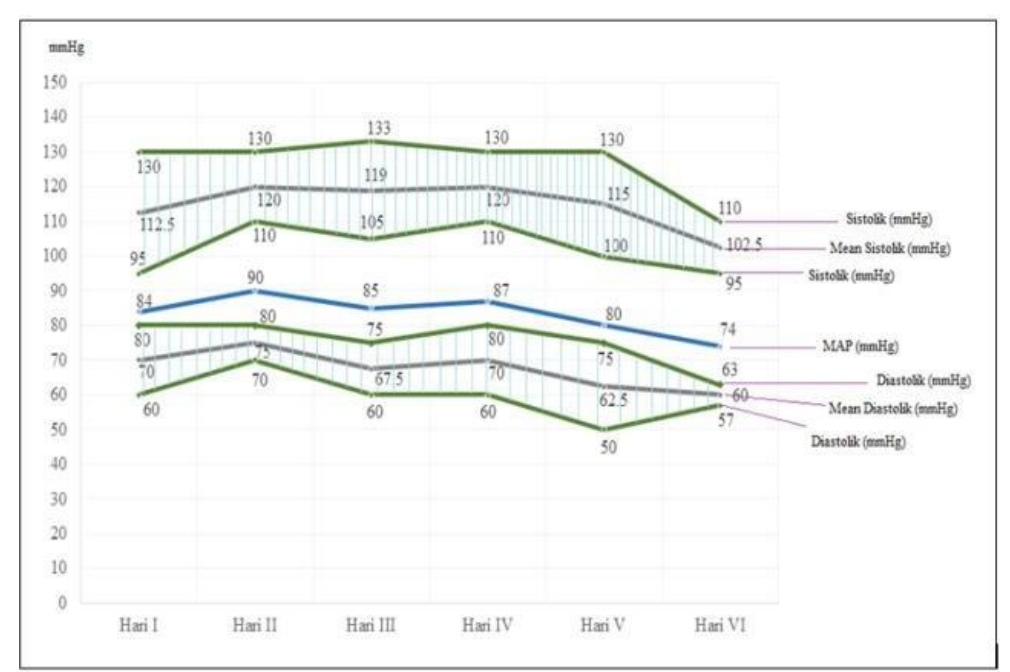

Grafik 1. Rentang tekanan darah Sistolik - Diastolik dan MAP

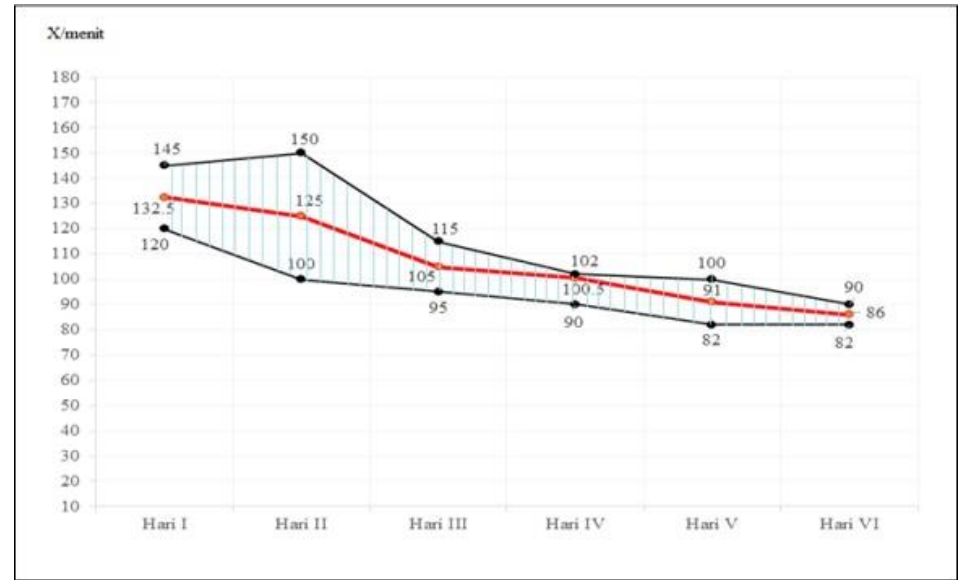

Grafik 2. Rentang heart rate.

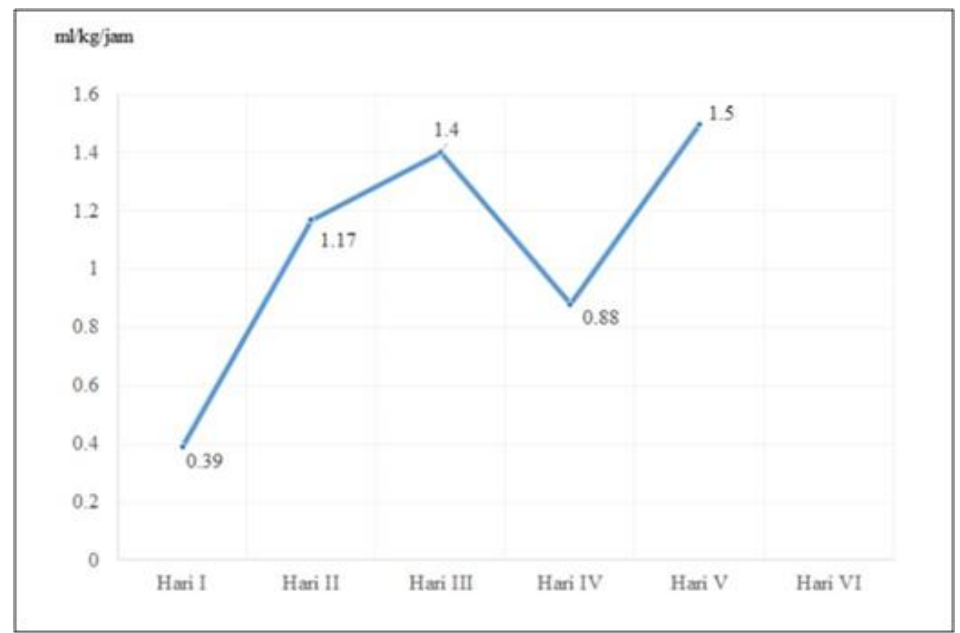

Grafik 3. Urine output 


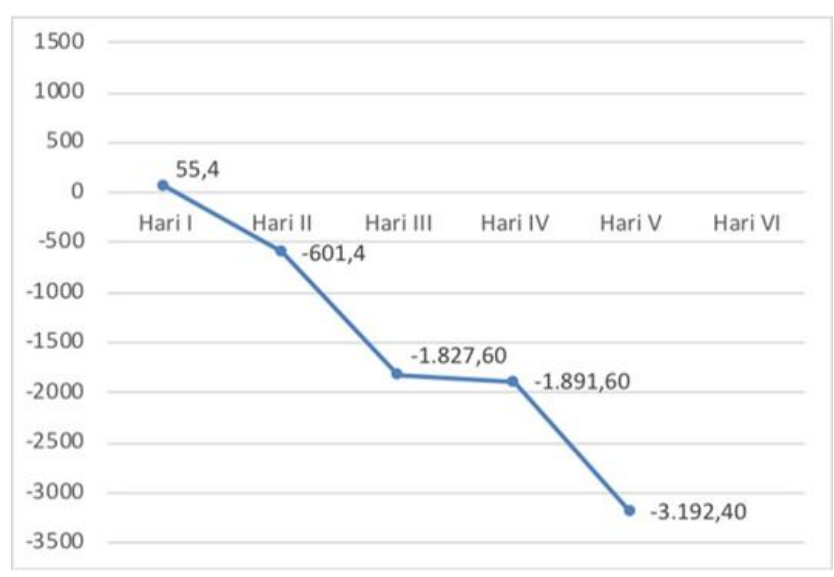

Grafik 4. Balans cairan kumulatif.

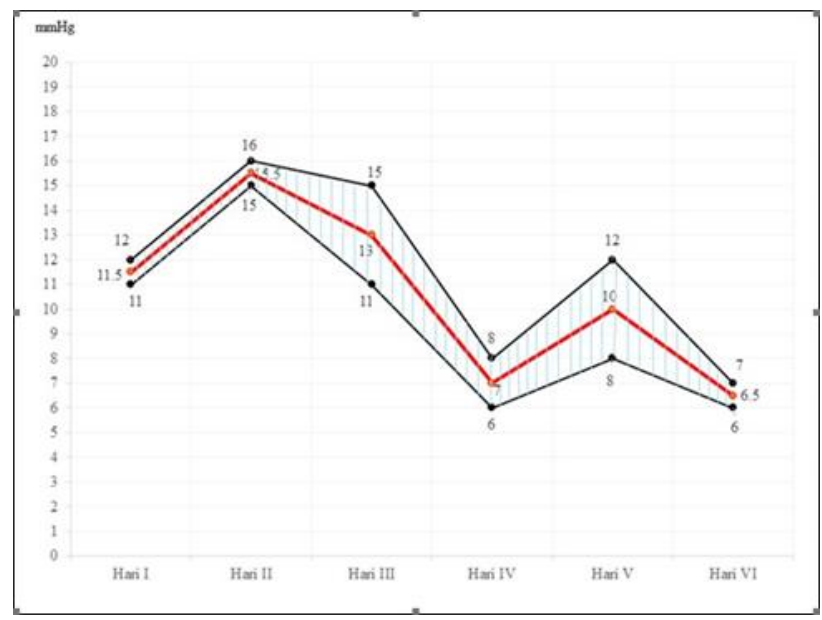

Grafik 5. Nilai CVP

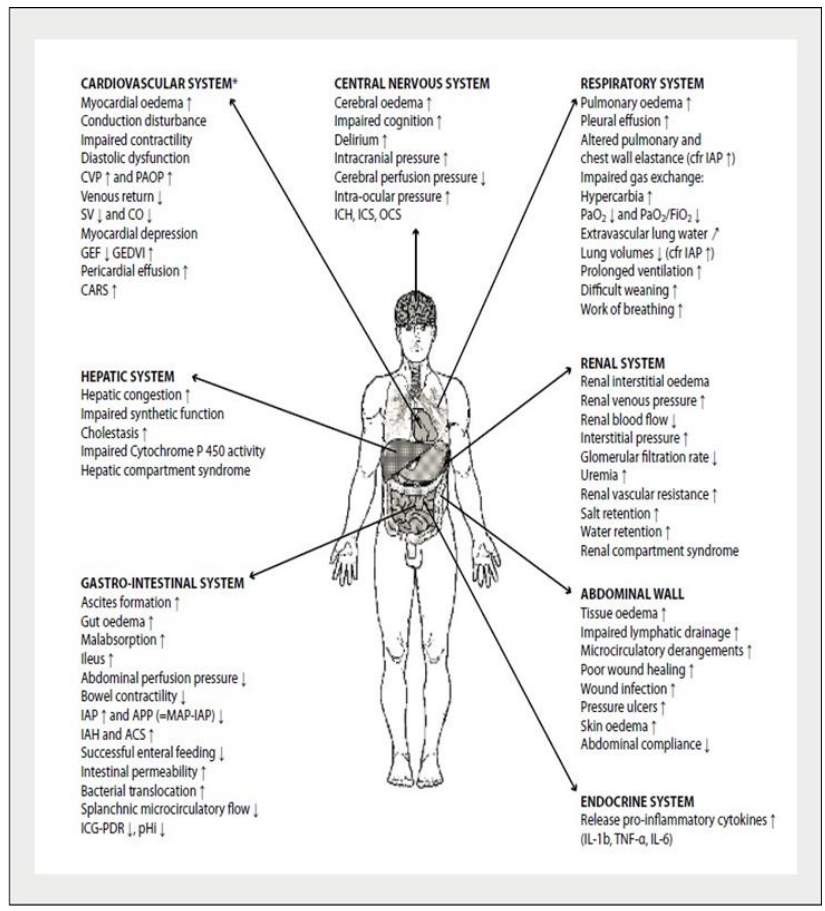

Gambar 2. Efek patofisiologis dari fluid overload terhadap berbagai organ tubuh 
Tabel 2. Parameter balans cairan kumulatif, dobutamin, milrinone, dan hemoglobin/hematokrit.

\begin{tabular}{|c|c|c|c|}
\hline Parameter & $\begin{array}{l}\text { Hari I } \\
(23-24 / 2 / 2019) ; \\
\text { Jam: 16.00-06.00 }\end{array}$ & $\begin{array}{l}\text { Hari II } \\
(24-25 / 2 / 2019) ; \\
06.00-06.00\end{array}$ & $\begin{array}{l}\text { Hari III } \\
\text { 26/2/2019); } \\
\text { Jam: } 06.00-06.00\end{array}$ \\
\hline Balans cairan & $+55,4$ (14 jam $)$ & $-801,4$ & $-1827,6$ \\
\hline $\begin{array}{l}\text { kumulatif (ml) } \\
\text { Dobutamin } \\
\text { (mcg/kg/menit) }\end{array}$ & $\begin{array}{l}3-5 \mathrm{mcg} / \mathrm{kg} / \mathrm{menit} \text {, } \\
\text { iv (titrasi) }\end{array}$ & $\begin{array}{l}3-5 \mathrm{mcg} / \mathrm{kg} / \mathrm{menit} \text {, } \\
\text { iv (titrasi) }\end{array}$ & $\begin{array}{l}\text { 1-3 } \mathrm{mcg} / \mathrm{kg} / \mathrm{menit} \text {, } \\
\text { iv (titrasi) }\end{array}$ \\
\hline $\begin{array}{l}\text { Milrinone } \\
(\mathrm{mcg} / \mathrm{kg} / \mathrm{menit})\end{array}$ & $\begin{array}{l}0,1-0,2 \\
\mathrm{mcg} / \mathrm{kg} / \mathrm{menit}, \\
\text { iv (titrasi) }\end{array}$ & $\begin{array}{l}0,1-0,2 \mathrm{mcg} / \mathrm{kg} / \mathrm{menit}, \mathrm{iv} \\
\text { (titrasi) }\end{array}$ & $\begin{array}{l}0,05-0,1 \\
\mathrm{mcg} / \mathrm{kg} / \mathrm{menit}, \\
\text { iv (titrasi) }\end{array}$ \\
\hline $\begin{array}{l}\text { Hemoglobin } \\
\text { Hematokrit } \\
\text { (gr/dl / \%) }\end{array}$ & $10,3 / 31,0$ & $8,5 / 25,5$ & $9,3 / 28,1$ \\
\hline
\end{tabular}

\begin{tabular}{|c|c|c|c|}
\hline Parameter & $\begin{array}{l}\text { Hari IV } \quad \text { (26- } \\
\text { 27/2/2019); } \\
\text { Jam: } 06.00-06.00\end{array}$ & $\begin{array}{l}\text { Hari V } \\
(27-28 / 2 / 2019) ; \\
06.00-06.00\end{array}$ & $\begin{array}{l}\text { Hari VI } \\
(28 / 2 / 2019) ; \quad \text { Jam: } \\
06.00-09.00\end{array}$ \\
\hline $\begin{array}{l}\text { Balans cairan } \\
\text { kumulatif }(\mathrm{ml})\end{array}$ & $-1891,6$ & $-3192,4$ & +240 (dalam 3 jam $)$ \\
\hline $\begin{array}{l}\text { Dobutamin } \\
\text { (mcg/kg/menit) }\end{array}$ & $\begin{array}{l}\text { 1-3 } \mathrm{mcg} / \mathrm{kg} / \mathrm{menit} \\
\text { iv (titrasi) }\end{array}$ & $\begin{array}{l}1 \mathrm{mcg} / \mathrm{kg} / \mathrm{menit} \text {, iv } \\
\text { (titrasi) }\end{array}$ & - \\
\hline $\begin{array}{l}\text { Milrinone } \\
\text { (mcg/kg/menit) }\end{array}$ & $\begin{array}{l}0,05-0,1 \\
\mathrm{mcg} / \mathrm{kg} / \mathrm{menit}, \\
\text { iv (titrasi) }\end{array}$ & $\begin{array}{l}0,05 \mathrm{mcg} / \mathrm{kg} / \mathrm{menit} \text {, iv } \\
\text { (titrasi) }\end{array}$ & - \\
\hline Hemoglobin & & & \\
\hline $\begin{array}{l}\text { Hematokrit } \\
(\mathrm{gr} / \mathrm{dl} / \%)\end{array}$ & $9 / 27,6$ & $9,1 / 27,8$ & - \\
\hline
\end{tabular}

Dari tabel di atas tampak bahwa fluid removal yang dilakukan berpengaruh positif terhadap pemberian dobutamin dan milrinone, dimana dosisnya semakin berkurang dan tetap dipertahankan sampai dosis minimal pada hari $\mathrm{V}$, dihentikan pada hari VI. Fluid removal yang dilakukan juga tidak berlebihan sampai menyebabkan hipovolemia. Hal ini tampak dari rasio hemoglobin dan hematokrit yang tetap dalam batas normal.

Kombinasi antara fluid removal dengan target balans cairan kumulatif negatif, oksigenasi yang adekuat selama bantuan ventilasi maupun setelah ekstubasi, dan terapi dengan kombinasi agen farmakologis yang tepat telah bekerja secara sinergis dalam penyembuhan pasien ini.

Melalui tindakan fluid removal dengan target balans cairan kumulatif negatif, maka efek patofisiologis dari fluid overload terhadap kardiovaskular dapat dihindari/diatasi, dan secara simultan menurunkan preload dan volume intravaskuler. Oksigenasi yang adekuat menjamin fungsi organ/sel tetap baik dan menurunkan PVR. Terapi kombinasi agen farmakologis mengurangi beban afterload, meningkatkan kontraktilitas jantung, dan mengoptimalkan frekuensi nadi sehingga tidak takikardia lagi. Efek yang simultan dari pengelolaan di atas sangat signifikan dalam perbaikan kondisi pasien ini. 


\section{KESIMPULAN}

Telah dilaporkan sebuah kasus tentang fluid removal dengan target balans cairan negatif. Fluid removal dengan target balans cairan kumulatif negatif bekerja secara sinergis dan efektif dengan terapi medikamentosa seperti dobutamin, milrinone, digoksin, dan oksigenasi yang adekuat dalam perbaikan kondisi pasien ini. Fluid management merupakan sebuah tantangan berat karena baik hipervolemia maupun hipovolemia dapat menimbulkan efek yang serius terhadap status hemodinamik secara keseluruhan. Tata cara tradisional dengan resusitasi cairan yang agresif dapat memperburuk kondisi pasien. Fluid management-nya adalah mencapai target negative fluid balance. Untuk kasus ini, panduan fluid removal yang digunakan adalah kondisi klinis pasien secara umum, ditambah dengan parameter seperti: tekanan darah, frekuensi nadi, urine output, balans cairan kumulatif, tingkat kebutuhan akan obat- obat penopang hemodinamik, rasio hemoglobin/hematokrit, ureum, kreatinin, laktat, dan BE (parameter makro dan mikro dinamik). Panduan untuk weaning dan ekstubasi adalah kondisi klinis pasien secara umum, ditambah dengan parameter seperti: tekanan darah, frekuensi nadi, tingkat kebutuhan akan obat-obat penopang hemodinamik, $\mathrm{PaO}_{2} / \mathrm{FiO}_{2}$ ratio, $\mathrm{SpO}$, respiration rate, foto toraks, dan mode ventilasi.

\section{DAFTAR PUSTAKA}

1. Malbrain ML, Marik PE, Witters I, Cordemans C, et al. Fluid overload, de-resuscitation, and outcomes in critically ill or injured patients: a systematic review with suggestions forclinical practice. Anaesthesiology Intensive Therapy. 2014; 46: 36180.

2. Prowle JR, Echeverri JE, Ligabo EV, Ronco C, Bellomo R: Fluid balance and acute kidney injury. Nat Rev Nephrol. 2010; 6: 107-15.
3. Murphy CV, Schramm GE, Doherty JA, et al. The importance of fluid management in acute lung injury secondary to septic shock. Chest 2009; 136: 102-9

4. Silversides J, Fitzgerald E, Manickavasagam US, et al. Deresuscitation of Patients With Iatrogenic Fluid Overload Is Associated With Reduced Mortality in Critical Illness. Crit. Care Med. October 2018; 46 (10): 1600-7.

5. Wioedemann HP, Wheeler AP, Bernard GR, et al. Comparison of two fluid-management strategies in acute lung injury. New Engl J Med. 2006; 354: 2564-75.

6. Alsous F, Khamiees M, DeGirolamo A, Amoateng- Adjepong Y, et al. Negative fluid balance predicts survival in patients with septic shock: a retrospective pilot study. Chest. 2000; 117: 1749-54.

7. Cordeman C, De Iaet I, Van Regenmortel N, et al. Fluid management in critically ill patients: the role of EVLW, abdominal hypertension, capillary leak and fluid balance. Ann Intensive Care. 2012; 2 (Suppl 1): S1.

8. Kerbaul F, Rondelet B, Motte S, et al.: Effect of Norepinephrine and Dobutamin on pressure loadinduced right ventricular failure. Crit Care Med. 2004;32:1035-40.

9. Felker GM, Benza RL, Chandler $\mathrm{AB}$, et al.: Heart failure etiology and response to Milrinone in decompensated heart failure: Result from the OPTIME-CHF study. J Am Coll Cardiol. 2003;41:997-1003.

10. Setiawati A, Nafrialdi: Farmakologi dan Terapi: Seksi VI. Obat Kardiovaskular. Badan penerbit FKUI. 2012;5:299-313.

11. Yancy C W, Jessup M, Bozkurt B, Butler J, et al. 2013 ACCF/AHA Guideline for the Management of 
Heart Failure: Executive Summary. J Am Coll Cardiol. 2013;62:1495539.

12. Vamos M, Erath JW, Hohnsoler SH. Digoxin-associated mortality: a systematic review and meta-analysis of the literature. European Heart Journal. 2015;36(28):1831-8.

13. Teboul JL, Saugel B, Cecconi M, et al. Less invasive hemodynamic monitoring in critically ill patients: Intensive Care Med.
3016;42(9):1350-9.

14. Huygh J, Peeters Y, Bernards J, Malbrain ML. Hemodynamic monitoring in the critically ill: an overview of current cardiac output monitoring methods. F1000Research 2016;5:1-9.

15. Hoeper MM, Granton J: Intensive Care Unit management of patient with severe pulmonary hypertension and right heart failure. Am J Respir Crit Care Med. 2011;184:1114-24. 